Borneo Journal of Sciences and Technology, Volume (1), Issue (2), Pages: 09-15

DOI: https://doi.org/10.35370/bjost.2019.1.2-02

e-ISSN: 2672-7439

(C) 2019, UCTS Publisher.

$\begin{array}{lll}\text { Submitted: } 22^{\text {nd }} \text { February } 2019 & \text { Accepted: } 1^{\text {st }} \text { March } 2019 & \text { Published: } 31^{\text {st }} \text { July } 2019\end{array}$

\title{
The Effect of Soaking Condition on Mung Bean Vigna radiata Towards Water Absorption and Mung Bean Extracted Crude Protein Content
}

\author{
Abdul Fattah Ab Razak, Ting Ung Hua, Mohd Syafiq Abdullah, Norhasmillah Abu Hassan \\ School of Engineering and Technology, University of College Technology Sarawak, Sibu 96000, \\ Sarawak Malaysia
}

\begin{abstract}
In this study, the effect of soaking condition towards Mung bean Vigna radiata water absorption and Mung bean extracted crude protein were investigated. This research was conducted to fulfill the fundamental study on the development of Mung bean beverage. The factorial design was employed to investigate the effect of soaking condition by 3 factors, namely concentration of $\mathrm{NaHCO}_{3}(0.0 \%, 0.5 \%$ and $1.0 \%)$, temperature $\left(30^{\circ} \mathrm{C}, 60^{\circ} \mathrm{C}\right.$ and $\left.90^{\circ} \mathrm{C}\right)$ and time (30 minutes, 60 minutes and 90 minutes), under 19 runs and 2 responses: water absorption (\%) and crude protein $(\%)$. The data were then statistically analysed using Design Expert 7.0 software and results were generated under Anova table $(\mathrm{p}<0.05)$, interaction model graph and cube view, to predict the optimum soaking condition which best suits the required responses. It was found that the combination of 90 minutes soaking time, $30^{\circ} \mathrm{C}$ of soaking temperature and $1.0 \% \mathrm{NaHCO}_{3}$ concentration yielded the highest percentage of water absorption and crude protein.
\end{abstract}

Keywords: Soaking condition, mung bean, water absorption, crude protein.

\section{INTRODUCTION}

Mung bean or Vigna radiata is under Fabaceae family and widely grown in Asia and Africa. In the meantime, Australia has ranked this plant as pioneer cultivated commercial varieties since 1960s [1]. Generally, legumes are physically hard in texture, through soaking process the legume hardness structure able to be soften. Soaking has enable water to be evenly distributed among the macromolecules like protein and starch. According to Zamindar et al., [10], the softened legume is resulted from the beginning of prolong soaking time, as the water penetrated into the seed coat and reach to the centre of legume. Subsequently, water absorption phenomena reduce the legume hard structure. Protein content is considered most crucial aspect for human consumption. Mung bean cotyledon consists higher amount of protein content. Mung bean at dry state has $20 \%-24 \%$ of protein and considered the major storage of albumin and salt - soluble globulin that supply to the total protein content of $60 \%$ and $25 \%$ respectively for the total protein content [9]. Although mung bean is rich in protein, it has been discovered that some proteins content are allergenic as they affect Ig-E mediated reactions [5]. The water absorption capacity is dependent on mung bean varieties [4]. Therefore, in this paper the effect of soaking condition towards mung bean water absorption and extracted crude protein of mung bean were investigated.

\section{MATERIALS AND METHODS}

\section{Source of Materials}

Mung bean (Vigna radiata) were purchased from local supermarket in Sibu and transported to laboratories and stored at ambient temperature.

\section{Experimental Design}

Factorial design technique was applied to identify the effect of soaking condition towards mung bean water absorption and extracted crude protein content. Both experimental design and statistical analysis were performed using Design - Expert Version 7 (Stat Ease Inc., USA). Three factors and three levels were chosen to assess the combined effect of three variables: Soaking temperature $\left({ }^{\circ} \mathrm{C}\right)$, soaking time (minutes) and concentration of sodium bicarbonate $\left(\mathrm{NaHCO}_{3}\right)$ (\%). There were 19 runs conducted including four points to the center points. The lowest, middle and highest values for soaking temperature were fixed at $30^{\circ} \mathrm{C}, 60^{\circ} \mathrm{C} 90^{\circ} \mathrm{C}$. Soaking time with lowest, middle and highest value were designated at 
30 minutes, 60 minutes and 90 minutes. The percentage of $\mathrm{NaHCO}_{3}$ concentration were set at $0.0 \%, 0.5 \%$ and $1.0 \%$. The dependent variables were the mung bean water absorption and mung bean extraction of crude protein.

\section{Preparation of Soaking Medium}

Three different of mung bean soaking mediums were prepared according to the concentration of $0.0 \%$, $0.5 \%$ and $1.0 \%$ of $\mathrm{NaHCO}_{3} .0 .0 \%$ soaking medium was acknowledged as control sample and was prepared using distilled water with no presence of $\mathrm{NaHCO}_{3}$. On the other hand, $0.5 \%$ and $1.0 \%$ of soaking medium were prepared by mixing $10.5 \mathrm{~g}$ and $20.2 \mathrm{~g}$ of $\mathrm{NaHCO}_{3}$ powder with distilled water in $2 \mathrm{~L}$ volumetric flask respectively.

\section{Water Absorption (\%)}

The water absorption for each sample were determined according to technique applied by Pan $\&$ Tangratanavalee [8]. $30 \mathrm{~g}$ of sample was initially weighed and soaked accordingly. After reaching the required soaking time, each sample were strained using muslin cloth and the weighed of the soaked sample was taken.

The water absorption was quantified by using the following equation:

$$
\begin{aligned}
& \text { WA }=\begin{array}{l}
\frac{W_{2}-W_{1}}{W_{1}} \\
\text { Where }
\end{array} \\
& W_{2}=\text { Weight of mung bean after soaked } \\
& (\mathrm{g}) \\
& W_{1}=\text { Weight of mung bean before soaked } \\
& (\mathrm{g})
\end{aligned}
$$

\section{Preparation of Mung Bean Extraction}

The soaked mung beans were further mixed with filtered water in the ratio of 1:8 and ground for 10 minutes at low speed using Waring blender, USA. The mixture was filtered using muslin cloth. The filtrate was separated for further analyses, while the remained was discarded.

\section{Crude Protein Analysis}

The extract of mung bean crude protein content was analysed according to AOAC method 991.20 for total nitrogen measurement in milk technique [3].

\section{RESULTS AND DISCUSSION}

\section{The Effect of Soaking Condition towards Mung Bean Water Absorption Rate.}

As reported in the Illinois method, soaking is considered as pretreatment in this research. Soaking and percentage of water absorption uptake are interrelated. According to Huma et al., [4], legume which undergone soaking process will absorb certain percentage of soaking medium. Swollen, soften in texture, increase in volume, weight and size are the effect of continuous soaking process towards legume. As indicated in Table 1, the soaking condition of $0.0 \% \mathrm{NaHCO} 3,90^{\circ} \mathrm{C}$ and 90 minutes under sample number 1 recorded $146.60 \%$, thus signified the highest water absorption rate. Meanwhile, the lowest water absorption rate of mung bean samples is under the condition of $1.0 \% \mathrm{NaHCO}_{3}, 30^{\circ} \mathrm{C}$ and 30 minutes at sample number 19 which recorded $11.46 \%$.

Therefore, it can be assumed that an increase of temperature and time results in an increase of water absorption rate. The application of $\mathrm{NaHCO}_{3}$ in this study is to reduce the beany flavour content in mung bean [11]. With an appropriate soaking condition through combination of heat treatment and concentration of $\mathrm{NaHCO}_{3}$, the loss of natural colour and the chemical changes could be significantly reduced. Tannins which was found in most legumes are brown pigments which associated in formation of beany flavour [12]. Consequently, the utilization of alkali soaking medium is unlikely affect the mung bean water absorption rate. The results are further analysed by Design - Expert software and present in Table 2.

From table 2, it is found that the concentration of $\mathrm{NaHCO}_{3}$ is not significant towards mung bean water absorption rate. $\mathrm{P}$ value $<0.0001$ which is in agreement to the hypothesis that temperature and time affect mung bean water absorption rate. Figure 1 shows the interaction model graph between time and temperature towards water absorption rate. 
The Effect of Soaking Condition on Mung Bean Vigna radiata Towards Water Absorption and Mung Bean Extracted Crude Protein Content

Table 1: The effect of soaking condition towards mung bean water absorption (\%), and crude protein of mung bean extraction $(\%)$

\begin{tabular}{|c|c|c|c|c|c|}
\hline $\begin{array}{l}\text { Sample } \\
\text { Number }\end{array}$ & & Soaking Condition & $\begin{array}{c}\text { Water } \\
\text { absorption, \% }\end{array}$ & $\begin{array}{l}\text { Average Water } \\
\text { Absorption }(\%)\end{array}$ & Crude Protein (\%) \\
\hline 2 & $0.0 \%$ & $\mathrm{NaHCO}_{3}, 30^{\circ} \mathrm{C}, 30 \mathrm{~min}$ & 21.23 & \multirow{2}{*}{23.20} & 1.6942 \\
\hline 8 & $0.0 \%$ & $\mathrm{NaHCO}_{3}, 30^{\circ} \mathrm{C}, 30 \mathrm{~min}$ & 25.17 & & 2.1009 \\
\hline 7 & $0.0 \%$ & $\mathrm{NaHCO}_{3}, 30^{\circ} \mathrm{C}, 90 \mathrm{~min}$ & 23.49 & \multirow{2}{*}{25.80} & 1.6677 \\
\hline 10 & $0.0 \%$ & $\mathrm{NaHCO}_{3}, 30^{\circ} \mathrm{C}, 90 \mathrm{~min}$ & 28.11 & & 1.6595 \\
\hline 3 & $0.0 \%$ & $\mathrm{NaHCO}_{3}, 90^{\circ} \mathrm{C}, 30 \mathrm{~min}$ & 60.99 & \multirow{2}{*}{64.96} & 0.7219 \\
\hline 17 & $0.0 \%$ & $\mathrm{NaHCO}_{3}, 90^{\circ} \mathrm{C}, 30 \mathrm{~min}$ & 68.93 & & 0.6584 \\
\hline 1 & $0.0 \%$ & $\mathrm{NaHCO}_{3}, 90^{\circ} \mathrm{C}, 90 \mathrm{~min}$ & 146.60 & \multirow{2}{*}{141.50} & 0.1501 \\
\hline 15 & $0.0 \%$ & $\mathrm{NaHCO}_{3}, 90^{\circ} \mathrm{C}, 90 \mathrm{~min}$ & 136.40 & & 0.1949 \\
\hline 5 & $0.5 \%$ & $\mathrm{NaHCO}_{3}, 60^{\circ} \mathrm{C}, 60 \mathrm{~min}$ & 41.67 & \multirow{4}{*}{40.80} & 1.3445 \\
\hline 12 & $0.5 \%$ & $\mathrm{NaHCO}_{3}, 60^{\circ} \mathrm{C}, 60 \mathrm{~min}$ & 39.30 & & 1.4583 \\
\hline 13 & $0.5 \%$ & $\mathrm{NaHCO}_{3}, 60^{\circ} \mathrm{C}, 60 \mathrm{~min}$ & 41.31 & & 1.2284 \\
\hline 16 & $0.5 \%$ & $\mathrm{NaHCO}_{3}, 60^{\circ} \mathrm{C}, 60 \mathrm{~min}$ & 40.93 & & 1.2129 \\
\hline 6 & $1.0 \%$ & $\mathrm{NaHCO}_{3}, 30^{\circ} \mathrm{C}, 30 \mathrm{~min}$ & 22.26 & \multirow{2}{*}{16.86} & 1.6844 \\
\hline 19 & $1.0 \%$ & $\mathrm{NaHCO}_{3}, 30^{\circ} \mathrm{C}, 30 \mathrm{~min}$ & 11.46 & & 1.0938 \\
\hline 9 & $1.0 \%$ & $\mathrm{NaHCO}_{3}, 30^{\circ} \mathrm{C}, 90 \mathrm{~min}$ & 29.57 & \multirow{2}{*}{33.03} & 1.8193 \\
\hline 20 & $1.0 \%$ & $\mathrm{NaHCO}_{3}, 30^{\circ} \mathrm{C}, 90 \mathrm{~min}$ & 36.50 & & 1.6978 \\
\hline 11 & $1.0 \%$ & $\mathrm{NaHCO}_{3}, 90^{\circ} \mathrm{C}, 30 \mathrm{~min}$ & 63.64 & \multirow{2}{*}{58.58} & 1.4583 \\
\hline 14 & $1.0 \%$ & $\mathrm{NaHCO}_{3}, 90^{\circ} \mathrm{C}, 30 \mathrm{~min}$ & 53.53 & & 1.3563 \\
\hline 4 & $1.0 \%$ & $\mathrm{NaHCO}_{3}, 90^{\circ} \mathrm{C}, 90 \mathrm{~min}$ & 125.42 & \multirow{2}{*}{131.22} & 0.4018 \\
\hline 18 & $1.0 \%$ & $\mathrm{NaHCO}_{3}, 90^{\circ} \mathrm{C}, 90 \mathrm{~min}$ & 137.01 & & 0.2359 \\
\hline
\end{tabular}

Table 2: ANOVA table for the analysis of water absorption (\%)

\begin{tabular}{cccccc}
\hline Source & $\begin{array}{c}\text { Sum of } \\
\text { Squares }\end{array}$ & Df & $\begin{array}{c}\text { Mean } \\
\text { Square }\end{array}$ & F Value & $\begin{array}{c}\text { p-value } \\
\text { Prob }>\text { F }\end{array}$ \\
\hline Model & 33408.58 & 3 & 11136.19 & 306.60 & $<0.0001$ \\
A-Time & 7051.38 & 1 & 7051.38 & 194.14 & $<0.0001$ \\
$\begin{array}{c}\text { B- } \\
\text { Temperature }\end{array}$ & 22106.49 & 1 & 22106.49 & 608.63 & $<0.0001$ \\
AB & 4250.71 & 1 & 4250.71 & 117.03 & $<0.0001$ \\
Curvature & 1423.58 & 1 & 1423.58 & 39.19 & $<0.0001$ \\
Pure Error & 305.86 & 11 & 27.81 & & \\
\hline
\end{tabular}




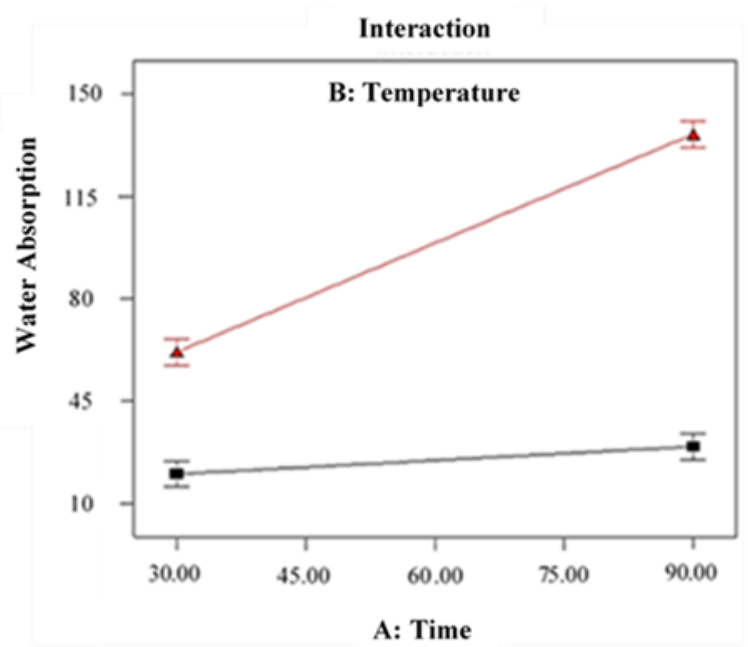

Figure 1: Model graph of interaction between time and temperature on water absorption

Figure 1, shows that the gap at lower temperature and time is relatively small as compare to the gap at higher temperature and time. This justified the effect of temperature on water absorption is significant at the high level of time. Thus, the water absorption of mung bean samples increase significantly for both time and temperature of soaking. This is also parallel with the study by Ros, G., \& Collins [9]. They found that the legumes were separated and its nutrients were released in the surrounding medium as it undergo heating treatment.

Based on the observation, the soaking conditions of $\left[0.0 \% \mathrm{NaHCO}_{3}, 30^{\circ} \mathrm{C}, 30 \mathrm{mins}\right],\left[0.0 \% \mathrm{NaHCO}_{3}, 30^{\circ} \mathrm{C}\right.$, 90 mins] and $\left[1.0 \% \mathrm{NaHCO}_{3}, 30^{\circ} \mathrm{C}, 30\right.$ mins] resulted a low water absorption and the mung bean structure was remained hard after the experiment was completed. Thus, these conditions were ineffective towards the main objective of soaking which is to reduce the hardness of legume. In the meantime, sufficient soaking is vital to remove raffinose, stachyose and antinutritional factors. In order to determine the optimum soaking condition, Design Expert 7.0 has translated this condition in the form of cube view.

Figure 2 depicts the cube view combination of three factors in soaking conditions namely soaking time, soaking temperature and concentration of $\mathrm{NaHCO}_{3}$ in affecting the response of mung bean water absorption. From the cube view, there are only four readings of water absorption generated since the concentration of $\mathrm{NaHCO}_{3}$ did not significantly interfere with water absorption. For the optimum soaking condition, the settings with high level of temperature which is more than $90.00^{\circ} \mathrm{C}\left(\mathrm{B}+: 90.00^{\circ} \mathrm{C}\right)$ are prevented as to maintain mung bean nutrition content.

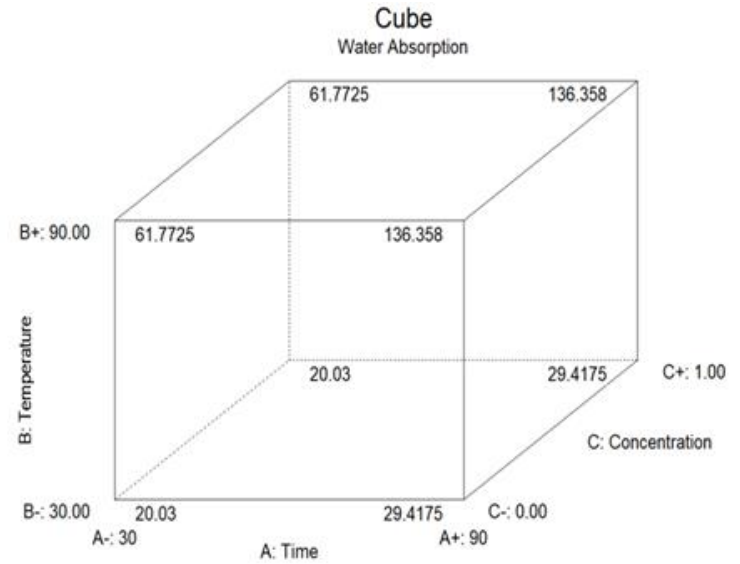

Figure 2: Cube view of the analysis of mung bean water absorption

In other words, the settings located at the upper four vertices are not considered. Hence, the adequate water absorption should be within the range of $20.03 \%$ to $61.77 \%$. However, the condition of mung bean at $20.03 \%$ which resulted a lower water absorption failed to achieve the soften structure. On the other hand, the condition which resulted $25.80 \%$ of water absorption as shown in Table 1 , able to alter the structure of mung bean legume. Therefore, the recommended lower water absorption result should be within the range of $25.80 \%$ until $61.77 \%$.

\section{The Effect of Soaking Condition towards Extracted Crude Protein of Mung Bean}

From Table 1, it is found that the effect of soaking condition towards extracted crude protein of mung bean is typically low, ranging from 0.1501 to $2.1009 \%$. Soybean at native state contain $36-56 \%$ of protein [2]. On the other hand, the mung bean protein content at dry form is ranged from $14.6 \%$ to $33.0 \%$ [7]. Legumes protein denaturation is coherent with the presence of heat treatment Khattab et al., [5]. Nout et al., [7] reported that longer processing period of time and higher temperature affect the loss of lysine. Consequently, heat treatment also influence the decrease of total sulphur amino acids, tryptophan and threonine. 


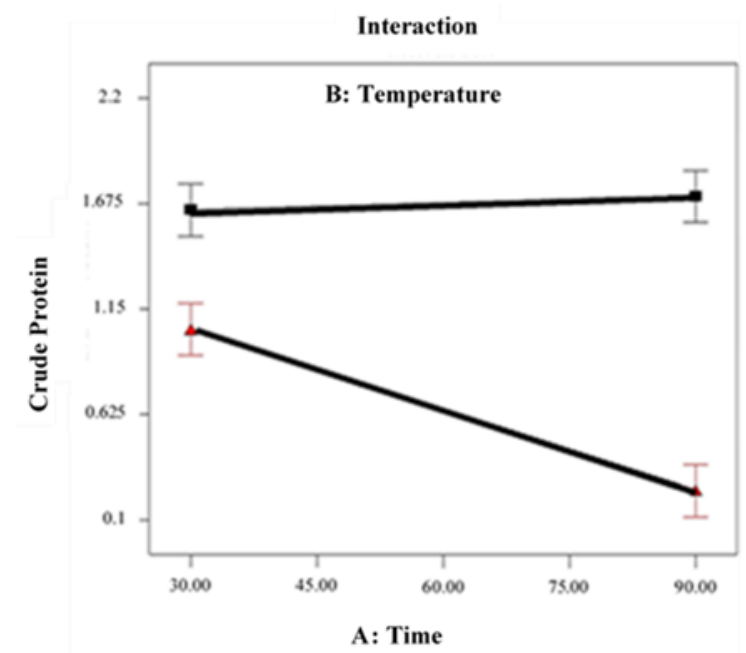

Figure 3: Model graph of interaction between time and temperature on crude protein

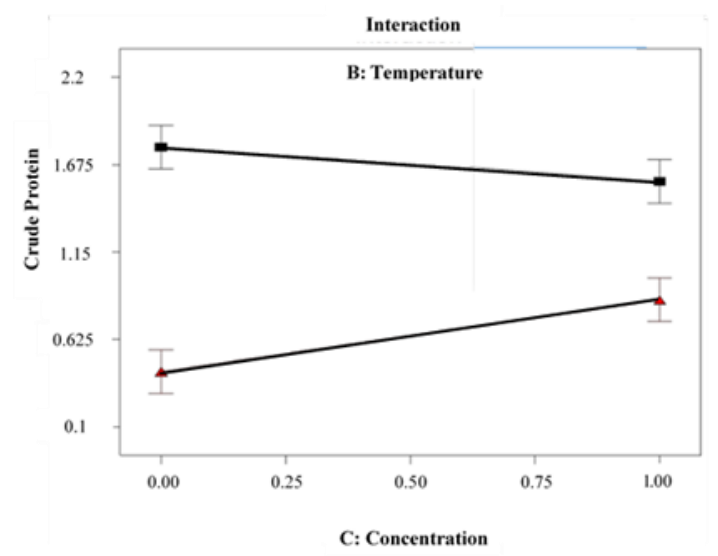

Figure 4: Model graph of interaction between concentration of $\mathrm{NaHCO} 3$ and temperature on crude protein

Table 3 represents the ANOVA interaction between soaking time, soaking temperature and concentration of $\mathrm{NaHCO}$. It can be interpreted that the loss of mung bean crude protein do correlate with soaking time and soaking temperature, as 0.0004 and 0.0034 respectively ( $\mathrm{p}-$ value < 0.05). Based on Figure 3, it is observed that the gap at lower temperature and time is small as compare to the higher temperature and longer time. Thus, at low level of soaking time, the soaking temperature has less significant effect towards crude protein content.

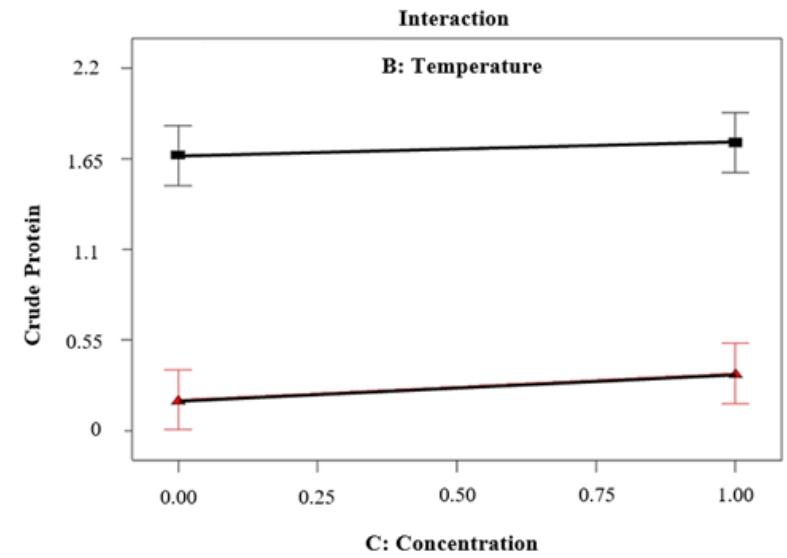

Figure 5: Model graph of interaction between concentration of $\mathrm{NaHCO}_{3}$ and temperature on crude protein (with extended time)

The interactions between concentration of $\mathrm{NaHCO}_{3}$ and soaking temperature were shown in Figure 4, determine that both factors have less significant effects towards mung bean crude protein extraction. This is due to the observation that the gap between lower concentrations of $\mathrm{NaHCO}_{3}$ and soaking temperature is wider than the gap at higher concentrations and soaking temperature. Besides, the gaps between points at the right side of the model graph shown in Figure 4 has changed wider as the time increased as shown in Figure 4. Hence, soaking medium with high concentration of $\mathrm{NaHCO}_{3}$ and longer soaking time brought significant effect on the crude protein content. To achieve high crude protein content, it is recommended that the condition should be high concentration of $\mathrm{NaHCO}_{3}$, longer soaking time and low soaking temperature. This recommendation is to be confirmed through the cube view in Figure 6.

As illustrated by the cube view shown at Figure 6, the maximum crude protein content is $1.90 \%$ that has the settings of low level of time (A-), low level of temperature (B-) and low level of $\mathrm{NaHCO}^{3}$ concentration ( $\mathrm{C}-$ ) which does not meet the recommended settings mentioned previously. The recommended settings of high level of soaking time $(\mathrm{A}+)$, low level of temperature (B-) and high level of $\mathrm{NaHCO}_{3}(\mathrm{C}+)$ yields the crude protein percent of $1.76 \%$ which adhere to the maximum crude protein in the cube. Although the recommended settings mode does not generate the maximum crude protein, it is in agreement with the condition of water absorption response. 


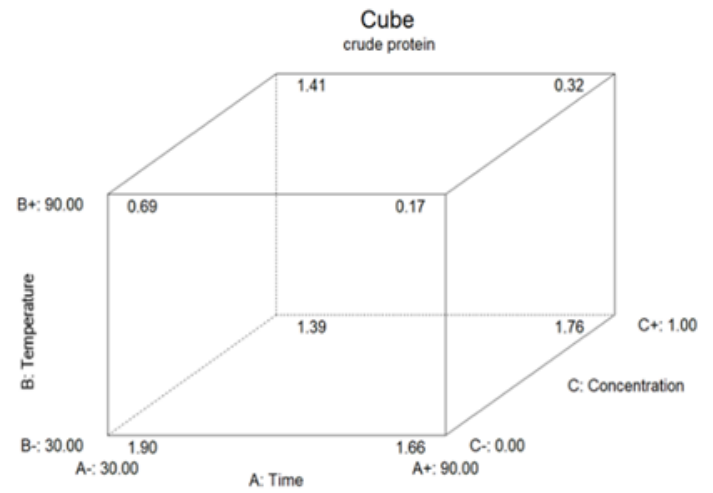

Figure 6: Cube view of the analysis on extraction of mung bean crude protein

Table 3: ANOVA table for the analysis of crude protein content

\begin{tabular}{llllll}
\hline Source & $\begin{array}{l}\text { Sum of } \\
\text { Squares }\end{array}$ & Df & $\begin{array}{l}\text { Mean } \\
\text { Square }\end{array}$ & $\begin{array}{l}\text { F } \\
\text { Value }\end{array}$ & $\begin{array}{l}\text { p-value } \\
\text { Prob > F }\end{array}$ \\
\hline Model & 6.35 & 7 & 0.91 & 30.61 & $<0.0001$ \\
A -Time & 0.54 & 1 & 0.54 & 18.25 & 0.0013 \\
B -Temperature & 4.24 & 1 & 4.24 & 143.28 & $<0.0001$ \\
C & 0.051 & 1 & 0.051 & 1.71 & 0.2178 \\
Concentration & & & & & \\
AB & 0.76 & 1 & 0.76 & 25.60 & 0.0004 \\
AC & $2.655^{-4} \times 10^{-4}$ & 1 & $2.655^{\times 10^{-4}}$ & $8.965^{\times 10^{-3}}$ & 0.9263 \\
BC & 0.41 & 1 & 0.41 & 13.77 & 0.0034 \\
ABC & 0.34 & 1 & 0.34 & 11.64 & 0.0058 \\
$\begin{array}{l}\text { Curvature } \\
\text { Pure Error }\end{array}$ & 0.071 & 1 & 0.071 & 2.39 & 0.1501 \\
Cor Total & 0.33 & 11 & 0.030 & & \\
\hline
\end{tabular}

CONCLUSION

The mung bean soaked in $1.0 \% \mathrm{NaHCO}_{3}$ solution at $30^{\circ} \mathrm{C}$ for $90 \mathrm{~min}$ are found to have the optimum soaking condition in terms of water absorption and crude protein. It is vital to apply low soaking temperature while prolong the soaking time in order to achieve a desirable texture after soaking and reduce the potential of protein loss. The mung bean extract could be recommended as an alternative for legume beverage drink. However, the extracted crude protein of mung bean is considered low, compared to: soy bean extract, almond extract and hemp extract. This condition could be improved through addition of other legume extract with high protein content. Despite crude protein analysis conducted, the mung bean extract mineral analysis profile should be performed to investigate the nutritional quality of mung bean extract.

\section{ACKNOWLEDGMENT}

This project is supported under University College of Technology Sarawak internal research grant (UCTS/RESEARCH/<1/2018/01> (1).
REFERENCES

[1] A report: AgriFutures Australia, 2017. Mungbeans. [online] Available at: <http://www.agrifutures.com.au/farmdiversity/mungbeans/> [Accessed 22 April 2018].

[2] A report: Arnarson, A., 2015. Soybeans 101: Nutrition Facts and Health Effects. [online] Available at: <https://www.healthline.com/nutrition/foods/soybe ans> [Accessed 16 September 2018].

[3] AOAC., 2016. Official Methods of Analysis of AOAC International. 20th ed. Maryland, USA.

[4] Huma, N., Anjum, F. M., \& Sehar, S. (2008). Effect of soaking and cooking on nutritional quality and safety of legumes.

[5] Khattab, R. Y., Arntfield, S. D., \& Nyachoti, C. M. (2009). Nutritional quality of legume seeds as affected by some physical treatments, Part 1: Protein quality evaluation. LWT - Food Science and Technology, 42(6).

[6] Misra, A. Ã., Kumar, R., Mishra, V., Chaudhari, B. P., Raisuddin, S., Das, M., \& Dwivedi, P. D. (2011). Potential allergens of green gram (Vigna 
radiata L . Millsp ) identified as members of cupin superfamily and seed albumin Clinical \& Experimental Allergy, 1157-1168.

[7] Nout, M. J. R., Linnemann, A. R., Boekel, M. A. J. S. Van, \& Khetarpaul, N. (2015). Mung Bean: Technological and Nutritional Potential Mung Bean : Technological, 8398.

[8] Pan, Z., \& Tangratanavalee, W. (2003). Characteristics of soybeans as affected by soaking conditions. LWT - Food Science and Technology, 36(1), 143-151.

[9] Ros, G., \& Collins, J. L. (1993). Mineral Loss in Cowpeas [Vigna unguiculata Pressure Heating in Water, 58(4), 0-2.

[10] Sathe, S. K. (2002). Dry Bean Protein Functionality, 22(2), 175-223.
[11] Sethi, S., Tyagi, S. K., \& Anurag, R. K. (2016). Plant-based milk alternatives an emerging segment of functional beverages: a review. Journal of Food Science and Technology, 53(9), 3408-3423.

[12]Zamindar, N., Baghekhandan, M. S., Nasirpour, A., \& Sheikhzeinoddin, M. (2013). Effect of line, soaking and cooking time on water absorption, texture and splitting of red kidney beans. Journal of Food Science and Technology, 50(1), 108-114.

[13]Zhanli, L. (2008). Optimization of Preparation Technique for Mung Bean Milk. Journal of Anhui Agricultural Sciences, 36(2), 739. 